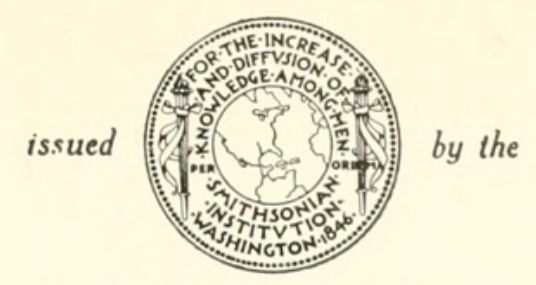

SMITHSONIAN INSTITUTION

U. S. NATIONAL MUSEUM

\title{
A SUPPOSED JELLYFISH FROM THE PRE-CAMBRIAN OF THE GRAND CANYON
}

By R. S. Bassler

THE search for fossils in pre-Cambrian rocks has always intrigued the geologist, but the comparatively few discoveries have led to almost as many controversial discussions, some of which are now classic in the literature. Pre-Cambrian fossils so interested the late Dr. Charles D. Walcott that he spent many months of his long, busy life in the discovery and interpretation of their remains. Shortly after his death, Mrs. Mary Vaux Walcott, in memory of her husband, established the Charles Doolittle Walcott medal and honorarium, to encourage further researches upon the paleontology of the earliest sedimentary rocks. The outcrops of the little metamorphosed preCambrian strata in which fossils might be expected are usually in more or less inaccessible regions where collecting presents difficulties other than those of finding specimens. Besides, the few fossils found have led to the belief that these strata instead of being marine might have originated upon the ancient continents.

The paucity of marine fossils in pre-Cambrian rocks makes it impossible to solve the problem of their origin. However, there must have been valid reasons for their apparent absence, since life was necessary at this time to account for the great abundance in the succeeding Cambrian rocks. Prof. William Keith Brooks believed that these oldest organisms lived at the surface of the ocean and lacked hard parts because the weight of the skeleton would have been detrimental to them. Dr. Walcott thought the pre-Cambrian strata were fresh-water deposits in lakes of low calcium content located considerable distances inland. Prof. T. C. Chamberlin suggested that all organisms originated on the land and did not reach the sea until early Paleozoic times. Daly's theory was that the pre- 
Cambrian marine organisms lacked calcareous parts because of insufficient calcium in the waters of that time. However, the great bodies of pre-Cambrian limestone and marbles would seem to preclude this idea. Prof. A. C. Lane considered the waters of the preCambrian oceans to be so acid that calcareous skeletons could not be formed. Prof. Percy E. Raymond followed Brooks' theory with the modification that skeletons appeared when a sluggish mode of existence was adopted. And, lastly, it is quite possible that the metamorphism of the rocks since pre-Cambrian times would account for most of the apparent absence, but then many of the strata are scarcely metamorphosed at all. Professor Raymond has elaborated these various theories in his address as retiring president of the Paleontological Society in $1934 .^{1}$

Although every object remotely resembling a fossil from the oldest strata of the Grand Canyon regions has been carefully collected and studied, so few have been accepted as real fossils that their number is almost negligible. These few have been classified as algae, sponges, and worm tracks, but there are students who deny that all these can be proved to be of organic origin. The discovery, therefore, of an imprint apparently of a jellyfish in the red sandstone of the Nankoweap middle group of the Grand Canyon series above the lavas forming the top of the Unkar lower group, by C. E. Van Gundy in 1935, and brought to the attention of scientists by Prof. Norman E. A. Hinds at the December 1937 annual meeting of the Carnegie Institution of Washington, is of great interest provided the specimen is correctly classified. Mr. Van Gundy ${ }^{2}$ in 1936 published an abstract of the stratigraphy of the Nankoweap group and mentioned the occurrence of this medusa as suggesting a marine environment for the beds containing it. The subject was discussed by Professor Hinds in $1938,{ }^{3}$ and he noted that this jellyfish is the only authenticated animal fossil discovered in the Grand Canyon pre-Cambrian, all others strongly suggesting the inorganic markings found throughout this series. Professor Hinds further stated the specimen had been identified as probably a jellyfish by the present writer and that a detailed description of it would be published later. Then, Dr. J. C. Merriam, president of the Carnegie Institution, under whose leadership the Grand Canyon researches were undertaken, presented the specimen to the United States National. Museum on the promise that it would be described. Since making this promise, the writer has become less certain of his first opinion as to the animal nature of the specimen, which was based upon its resemblance to Brooksella and

\footnotetext{
${ }^{1}$ Bull. Geol. Soc. Amer.. vol. 46, No. 3, pp. 375-392. 1935.

${ }^{2}$ Proc. Geol. Soc. Amer., 1936, p. 304.

Science, new ser., vol. 88, No. 2278, Aug. 26, 1938.
} 



\section{$2 \mathrm{BHL}$ Biodiversity Heritage Library}

Bassler, Ray S. 1941. "A supposed jellyfish from the pre-Cambrian of the Grand Canyon." Proceedings of the United States National Museum 89(3104), 519-522. https://doi.org/10.5479/si.00963801.89-3104.519.

View This Item Online: https://www.biodiversitylibrary.org/item/32570

DOI: https://doi.org/10.5479/si.00963801.89-3104.519

Permalink: https://www.biodiversitylibrary.org/partpdf/26194

\section{Holding Institution}

Smithsonian Libraries

\section{Sponsored by}

Smithsonian

\section{Copyright \& Reuse}

Copyright Status: NOT_IN_COPYRIGHT

Rights: https://www.biodiversitylibrary.org/permissions/

This document was created from content at the Biodiversity Heritage Library, the world's largest open access digital library for biodiversity literature and archives. Visit BHL at https://www.biodiversitylibrary.org. 